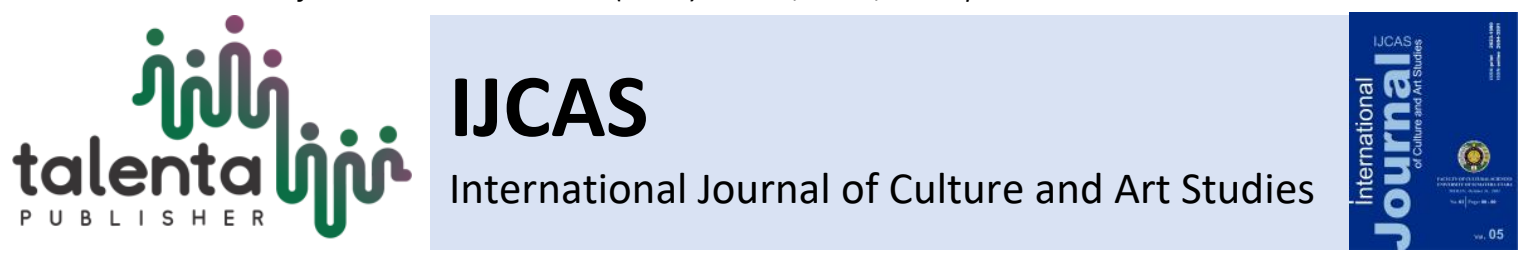

\title{
Analysis of Speech among Some Ethnic Groups in West Africa
}

\author{
Abdoulaye M'Begniga ${ }^{1 *}$, Yang Bo Ling ${ }^{2}$ \\ ${ }^{1}$ School of Literature, Anhui Normal University, Anhui, China \\ ${ }^{2}$ School of Journalism and Communication, Anhui Normal University, Anhui, China
}

\begin{abstract}
This research discusses the analysis of the concept of speech among some ethnic groups in West Africa. In fact, in West Africa, the art of speaking is brought to a high degree of perfection. According to those ethnic groups discussed in this paper, the speech possesses a mystical, talismanic power, which means that it has the power to protect and change the course of events. The Nommo's conception of life can illustrate this idea in that they consider that life itself lies on speech without which it can never exist. Also, they consider that there is a close relationship between speech and the speaker. However, speaking is more than just lining up words to be understood by the interlocutor, the audience. It is considered an art that must respect certain rules relating to the place, the time and the person speaking. In this sense, the researcher, in this paper, tries to analyze the concept of speech in these ethnic groups of West Africa. The research uses secondary data as the method, otherwise called "literature review". In other words, the researcher proceeded to collect the data related to the paper's topic by downloading them and then proceeded to the analyzes and comments.
\end{abstract}

Keywords: Concept, Oral, Ordinary, Proverb, Speech, Sacred

Received 17 August 2021 | Revised 24 September 2021 | Accepted 27 October 2021

\section{Introduction}

In general, Africa is considered to be a continent where orality is omnipresent. Thus, speech plays a major role in the mastery of knowledge and the transmission of the heritage of social groups. In this sense, in his article entitled "Oral Literature and Oral Civilization in Africa: Some Barriers to Remove for an Objective Approach to Modern African Culture," (Manbounggou et al., 1997) states: "Writing is a tool of speech. To express oneself orally is to convey messages using the spoken word as a means of communication."

In his book entitled "The speech in the African philosophical tradition: the status of the speech in the Egyptian moral thought of the pharaonic period", Fonkoué, J. (2009) lays out the details around the concept of the speech which, according to him, is not just a piece of language. In his logical, clear and precise reasoning, the author shows that, in African philosophy, the speech is an expressed thought and a strongly internalized ethical constant that gives each human being the

\footnotetext{
*Corresponding author at: School of Literature, Anhui Normal University, Wuhu, Anhui, People's Republic of China.
}

E-mail address: ambegniga@yahoo.fr 
full meaning of accomplishing his mission. According to the author, this African conception around the concept of speech also suggests that speech is essentially ethical in the African philosophical tradition and manifests itself in ritualized practices. In this vision, the discourse, that is to say, must be true, in agreement with that of the ancestors, in communion with the cosmos, with the Ma'at.

In West African oral societies, speaking shows and demonstrates. (Dembele, A, 2015) Thus, Matthieu Mermoud (2003) underlines: "The speech is the creator of the human community: it constitutes its first foundations. Whether written or oral, there is always a founding power in the enunciation."'[Ibid] According to the conception of these ethnic groups, the speech, when released from the lips as one loosens the strings of a talisman pouch, diffuses a special force, the primordial energy of creation itself. Following this logic regarding the concept of speech in these ethnic groups, The Tivs of Nigeria named the concept of life force "tsav", while the Fon of Benin named it "se". The analysis of these two terms is interesting in that they express "the power to bring change" (Paulette et al., 2008). Moreover, there is a saying that sums it all up: "Before speaking, you must stir your tongue in your mouth three times."

\section{Classification of Speech into Ordinary Speech and Sacred Speech}

\section{$2.1 \quad$ Ordinary speech}

This concept of "ordinary speech" can lead us to another phrase that people like to say in Africa "You must not speak to speak."It does not mean simple or unnecessary speech. In contrast, it is both very structured and well elaborated: we can find verbal images, metaphors, proverbs, sayings, aphorisms, etc. Thus, François N'SOUDAN, in his essay on the eYe people of South Togo, also makes the same observation: "In $e Y e$ society, speech is not reduced to the state of means; it is a system of very complex oral codes." (La littérature orale, source: http://ekladata.com) In everyday life, there is not only the existence of the art of conversation, but there are also "good speakers" who enjoy a reputation outside of their place of residence. Thus, their reputation crosses the borders of their village. Nowadays, recourse is made to the "good speakers" who must play the master of ceremonies and animator during the festivities. (Laditan, 2004] The speeches they pronounce during these events can thus be considered ordinary speeches that are also of paramount importance in their context. In addition, among the bamanans of Mali, there is what they call "kuma nafama", which can be translated as "useful speech". This notion of "kuma nafama" can be likened to that of "ordinary speech" in that it is not only important and useful but also plays a significant role in certain contexts. In fact, "kuma nafama" is there to unite and not to disunite, to restore a broken parental relationship and not to dramatize the break, to generate a social relationship and not to separate the bonds, to create and strengthen a marital bond and not to separate couples. In short, "ordinary speech," which is assimilated to the "kuma 
nafama" of the bamanans, can be considered as, according to the observation of François N'SOUDAN on the $e Y e$ people, a system of oral codes which is not only complex but also has some crucial role to play in society. In addition, the tales in those ethnic groups in West Africa, even if it uses what we may call "funny speech", can be considered "ordinary speech". Indeed, the tale uses the "fun" character of its "ordinary speech" to convey a useful message to society. Therefore, the tale is part of "kuma nafama", that is to say, "important speech" in this sense, even if its speech is considered to be "ordinary", it is still useful to society, especially in the education of children and young people who are the future of society. If the author François N'SOUDAN, in his essay on the $e Y e$ people, speaks of a system of oral and very complex codes, in the context of the African tale, only the narrator and his audience have the intellectual and reflective capacity to be able to decode these codes in his "ordinary speech". Rodrigue Homero Saturnin Barbe, in his article "Oral traditions in Africa: an exploration of storytelling as an inspiration for modern African theatre", says: "On the other hand, traditional storytelling in Africa generally uses seconddegree affabulation to express itself.

In most cases, let us remember, this art of speaking is used to awaken human consciousness. In other words, few tales are told to simply please or distract. As seen in Western societies, it is not used to rock and help children get to sleep. He acts beyond this individual need. Each tale in Africa needs to keep ignorant minds awake, raise awareness of the unwary, denounce anti-social and unjust behaviour, prevent community and individual misfortunes, etc. This is why the tale is part of the traditional spectacular collections always expressed in disguise, using a fictitious world and a detour from the events or realities of human society. (René Philombe et al., 1997) He has the advantage of speaking about humans while camouflaging himself in zoomorphic universes. We are talking about talking animals, who are more sensible, more united than human beings. This detour always refers to realities, to everyday life, to the daily life of men. If, for example, the monkey mocks the lion, this might reflect, to some extent, the relationship between men of power (the mighty, the strongest) and the little people. When it comes to social and political criticism, the traditional African tale is remarkably inspired when it uses a colourful style of public denunciation.” (Barbe, 2019)

\subsection{Sacred speech}

In so-called oral societies, we can say that speech is considered sacred. However, in West Africa, although it is considered sacred, there is also the other genre called "ordinary speech", analyzed previously. The sacred speech in West Africa refers to the ritual. Thus, ritual and sacred speech take a formalized form of everyday speech. A specific intonation, a primitive form, or a secret language characterizes ritual and sacred speech: the initiates. This speech has a very important role in the political-social, religious and mystical field, a non-negligible influence. Speech is the 
"texture of the world". Therefore, deprecated use can have serious consequences. That being said, the sacredness of the speech is found in practices that may seem unimportant but are full of deep meanings. In this sense, the manipulation of speech always remains a complex thing that requires a lot of attention. To retain the "magical power" that characterizes her, it is necessary to respect a certain number of rules and prohibitions. In addition, there is another speech whose formalized form makes it sacred. It is the speech that engages the actor. Indeed, involving the elders, particularly the ancestors and the gods through the speeches (promises), commits its author. With this kind of speech, the actor calls the ancestors to witness, and therefore he commits to them. Frequently, it is a lifelong commitment. Among the Dagara, this kind of speech is called nvor, that is to say, a vow or, more exactly, a vow involving a promise.

The fact of having established a pact between the author and an invisible power through this vow generated by said speech commits the latter, who will have no other choice but to comply with the sacredness that his speech now assumes. In the said pact, the vow maker gives his word that he will have no choice but to adhere to it scrupulously. Like the terms of a written contract between two people or two entities, the given speech sets out the pact's terms. In most cases, these terms refer to a request made by the perpetrator of the potency or ancestor. In return, he pledges to satisfy power with sacrifice. In some cases, the wish expressed may go beyond its author. In other words, it is likely to engage an entire community.

\section{Speech and the Transmission of Knowledge}

Through orality, most of the transmission of all knowledge and technical know-how has taken place in traditional West-African societies. Thus, the first mythical and founding stories were transmitted orally. This oral transmission prevailed until now. Even today, in some more distant places, especially in the bush in parts of West-Africa cultures, much knowledge is transmitted orally. The relationship with the sacred mentioned above is no stranger to this. In "Transmission of African oral tradition in exile", Simon Muke wrote this:

"The African oral tradition is less known in the Western world than African art because it has been little studied and has not known the same forms of dissemination. And yet, long before the arrival of Europeans, even before the development of writing, the peoples of sub-Saharan Africa have artistically expressed their deepest thoughts, feelings, and concerns, in the form of myths and legends, parables and tales, epic and genealogies, proverbs, riddles and riddles, songs." (Muke, 2008)

On the other hand, in Africa, the transmission of tradition (knowledge) is the business of some people, especially if it has repercussions on children's education. This is how the immediate family is involved in the knowledge transfer process in the same way as the "griots", true 
professionals of the speech, but also the storytellers, the singers, or even the African writers who, a little later, strive to incorporate tradition into their works.

In the family, the grandparents and the parents must get involved in the initiatory instruction of the children. Very frequently in West-Africa cultures, the father teaches his son and the mother, her daughter. As for the grandparents, it falls to them the most the transmission of the tradition to the children according to the wisdom procured by the age and their availability. They appear everywhere as important educational agents in fields not directly related to productivity, particularly in oral teaching. Besides grandparents and parents, there are also speech professionals commonly known as "griots" who, through their speech skills, can easily teach children and young people. (Mbathio Sall, http://origin-archive.ifla.org/IV/ifla65/65mb-f.htm)

\section{$4 \quad$ The status of speech}

The fact of not having used writing for a long time does not deprive West Africa of a past and knowledge. This knowledge is transmitted through oral tradition, that is to say, "The collection of all types of testimonies transmitted verbally by a people about their past."In Fact, in addition to the simple handling of the language that every child acquires in the first years of his life and which allows communication, the handling of speech, "speaking" is the subject, in West-African cultures, of great attention. In practice, it is considered the speaking that a man or a woman must know how to manage. "Speaking" is revealed as a living force that must be controlled. The human being is the one who speaks. Speaking characterizes man, the human being. Thus, in his study on the notions of happiness and suffering among the Peuls, Angelo B. Maliki (1984) expresses the feeling of a badaado woman as follows:

"Man has a breath of life, so does the beast. [...] However, the man is worth more than the beast. Because man is someone who can be spoken to and someone who can speak. Man is a being with whom we can dialogue. This is what makes the difference between man and beast. It is the superiority of man over beast. Even if it has a mind, a mouth, and a heart, a beast has no speech; it cannot speak. But the man is the speech." (Maliki, 1984)

This is also manifested by a Fulani saying which specifies, "the person is the speech." (Labatut, 1987) The Fon of Benin says that "speech is a measure of the personality of a human being." (Guédou, 1985) For the Gbaya bodoe of the Central African Republic, people are defined among other forms of life as "that which speaks"- animals can only cry (Roulon-Doko, 1998). This is what another observer like Geneviève Calame-Griaule (1965) notes:

"Concerning speech, Dogon thought divides the world into two categories: those of "beings who speak the word" and those of "beings who do not speak the word", of which the little child belongs in fact. " (Geneviève, 1965) 
In West Africa, to define man, the primary reference seems to be the speech. Moreover, the author Jacques Dournes distinguished the spoken from the oral. Indeed, in addition to the simple manipulation of the language that every child receives in the first years of his life and which allows communication, the manipulation of speech, the "spoken" is the object, in West-African cultures, of attention and is almost always considered to have consequences that everyone must know how to manage. It is a living force that must be controlled.

\section{The Art of speech}

In West-African oral cultures, the speech that holds a certain status, certain sacredness is not the prerogative of everyone because it covers a sensitivity that can be prey to considerable consequences in the community, in society, in a speech in the environment where it was used. A caste holds the speech; can we speak of ethnicity? Either way, they are called "the griots". Indeed, the cast of "griots" was born and then developed in a context where writing was non-existent. The "griot" is thus considered as being, in particular, the depositary of oral tradition. "Griotic" families may specialize in the country's history and genealogy, public speaking, musical practice, or practice all three, depending on the skill of each "griot". It is important, even necessary, to evoke the famous introduction by the Guinean writer D.T. Niane. The great "griot" Djeli Mamadou Kouyaté tells us about the "griot" his status, the important role that the griot plays in traditional African societies. This will allow us to get an idea of the holder of the word, of the power, and the art of the word "the griot":

"I am a "griot”. I am Djeli Mamadou Kouyaté, son of Bintou Kouyaté and Djeli Kedian Kouyaté, a master in the art of speaking. Since time immemorial, the Kouyate has been at the service of the Keita princes of Manding: we are the bags of speeches, we are the bags that contain secrets that are centuries old. The art of speaking has no secrets for us; without us, the names of kings would be forgotten, we are the memory of men; through words, we give life to the deeds and actions of kings in front of the younger generations. (Niane 1960, p. 9-10)

In his article entitled "The Griot and the Power, an ambiguous relation", Vincent Zanetti wrote:

"In West Africa, who says "griot" necessarily means oral tradition, and above all, the power of speech. In Mandingo society, the griot (djéli) is the craftsman of the verb, in the same way as the blacksmith (numun), who is that of metal: like him, he is "nyamakala" (craftsman, man of caste). An instrument of prestige for the powerful, arbiter of social conflicts, he can be a genealogist, or even a "doma", that is to say, a traditionalist, holder of legends and myths." (Vincent, 1990)

The postulate according to which "Any uttered speech preludes or leads to an action or a reaction whose immediate or distant effects - often irreversible - can be carriers of fatality or felicity." Recalled by Urbain Amoa in his article lets us know the delicate sensitivity that speech can have 
in its use. (Amoa, 2006) The sensitivity to certain frustrations, certain social tensions that the speech has when it is badly used, badly spoken means that the venerated old men endowed with great wisdom have learned not only to initiate the juvenile and childish generations the sacred principles which hatch the concept of the speech, but also they took care to delegate the power of its possession to a caste called "griots". The latter are moreover the initiators of young people and children to the concept of sacredness, which means that the speech's use must be the subject of careful consideration. In this sense, the author Urbain Amoa has found it useful to recall the three great lessons of wisdom that the African peoples teach us. These three wisdom lessons revolve around the concept of the sacredness of speaking, the need to exercise a certain level of wisdom not to speak for the sake of speaking, in a void by saying trivialities, and the usefulness of to speak because it will be of use to something primordial, valuable not only for the speaker but also and above all for the interlocutor. Among the Bamanan in Mali, there is a proverb that says: "Kuma ye tô den ye, ni mi djan to, i ni fila be wu li." This proverb is translated: "The speech is like a paste of "tô", if you are not careful, you will take two at the same time. The Bamoun proverb from Cameroon says, “A man's mouth burns him.” This proverb means, "Too much talk night." Other sayings about speech state: "What is in the speech is in silence." "Speech is silver and silence is gold," which means that it costs more. Speech is a wing of silence. Silence is sometimes wiser than speaking.

\section{The Power of Speech}

In fact, in the West-African conception around the concept of the "speech", in their wisdom around the sacred notion of the "speech", the speech, once released from the lips as one unties the strings of a talisman pouch, disseminates a special force, the primordial energy of creation itself. Among certain ethnic groups such as the Oro, referred to as the Yoruba of Nigeria and Benin, speaking is an exercise during which the speaker is naturally exhaling an active essence. About the Mande that we find in the tropical forests from the coast to the Sahel, speech is an embodiment of Nyama, in all its occult power, which can be at the same time creative, alternating, and beneficial. From this point of view, the speech has a talismanic power. This allows her to have the ability, the possibility, the power to protect, but at the same time; it can change the course of events. Among the Nommo, the idea that life is based on speech resonates throughout West Africa. The residual echo of the Bantus who left the region. Among the "Tivs" of northern Nigeria, the concept of life force is known as "tsav"; and among the "Fon" of Benin, se. These two terms express "the power to bring change." From his birth to his baptism, the protocol of the utterance of the incantation, the art or his initiation into certain occult, traditional practices until they are accompanied by speech, the child does not have his place in society, in the world. It is what is explicitly said that is powerful, abundant fertilization. In their philosophy vis-à-vis art, the technique of dialogue and conversation, as emblematic as they can be, the Nommo nurture the 
certainty that they give them their breath and their amplitude that are animated by generative and dynamic power. The Mande proverb says: "The speech is not in the hands of the people. People are in the hands of the speech."

The exchange of words between the speaker and the interlocutor, between the speaker and his audience, between the speaker and the audience that listens to him, the vitality of this exchange, of this conversation, of the dialogue - the very source of the fruitful power of certain ethnic groups including the Nommo, Oro, Nyama, which enlightens, corroborates, heals, corrects, and changes the world - is deeply inherent in the indigenous cultures of Africa. The discussion is "active", "energetic", "lively", "awake", it inspires an awakened, uninterrupted interdependence that activates all levels of West-African society. The Igbo proverb says well: "He who tells others what he is doing will not suffer any setback." Moreover, according to the Gokana proverb: "He who asks for public opinion has no difficulty." There is another proverb that states: "From old mouths to new ears." If the speech is considered an evaluation of man, it can only have value when spoken, expressed by an elder; the latter too must be an indisputable depository of common wisdom, accepted and approved by the entire world. Indeed, with the help of the wisdom he possesses, the sage can guide with the word in the manner of a bow guiding an arrow. So in the conception of the Igbos, it must look like a consultant consulting the oracle. The Efik are convinced that: "The speech of an old man is more important than all amulets." In a Toguna (palaver hut), somewhere in the Bandiagara corniche in Mali, the verbs of an old Dogon man breathe like the moist breath of the spirits of amphibious ancestors, which gives wisdom and order to the world. Indeed, in traditionally oral societies like those of West Africa, the wise and inspired word of Nommo looks like a process that must be continuous without any interruption. It must be repeated like a litany, recreated like an object in recycling, reinterpreted. Since these societies are traditionally oral, speaking is the object of all the processes previously mentioned, especially through the flourishing and constant traditions of storytelling that create myths, proverbs, tales, and songs. These are abundantly prevalent in said cultures. In addition, the Yoruba proverb states that: "The speech is the horse that the proverbs ride."

\section{$7 \quad$ The consideration of the speech as sacred}

Among the Yoruba, there is a proverb that says: "The mouth does not say all that the eyes see". Indeed, speaking is a very delicate thing that requires know-how, especially the respect of certain standards, to handle it. Regarding its sacredness, so that it can reserve all its "magic power", a certain number of rules and prohibitions must be observed. Concerning the prohibitions, they are numerous and can relate to the place and the moment of the speaking. They also relate to the lexicon, the speaker's gender, and age. From this point of view, it is forbidden to directly indicate the faecal function, the sexual organs, to mention certain painful, serious events such as the death of a tribal chief, etc. Louis-Vincent Thomas writes: "Where cultural choice lacks the support of 
writing, literature can only be oral (even if the expression seems contradictory) and willingly remains charged with force, both meaning and power; it, therefore, rubs shoulders with the sacred." (Thomas, 1993) Among the Yoruba, speech is of utmost importance. The exchange of speech is a very serious and important mode of communication in daily tribal life. There are essentially two types of speech: the first is ordinary speech, and the second is sacred speech. This reality is not observable only among the Yoruba. Indeed, the importance of speech in society is the same in all traditional West-African societies. This is to say that speaking is a fundamental element in the transmission of oral tradition.

Among the Bamanan, the majority ethnic group in Mali and whose dialect is the national spoken language, is called "Kuma". This term, bypassing it through the screens of careful analysis, is very interesting. Indeed, the term "Kuma" is the name derived from the verb "ka kuma". "Kuma" therefore means "speech", and "ka kuma" naturally means "To speak". Conversely, that is to say, "maku" means to be silent, not to speak. Therefore, the bamanan only means that if there is something important to say, there is necessarily a need to speak.

On the other hand, if there is no need to speak, that is to say, if what the speaker wants to express is of no use to the interlocutor, the audience, if they will not say than trivialities, it is better for him to be silent. It is as much to say that it is important to use good words. As part of the deepening of our analysis on this philosophy of the bamanan vis-à-vis the concept of speech, it is essential to underline the fact that they are not interested in the fact that some like to speak and that of others no, but rather the need to make use of good words at the right time and to an audience in need. In other words, the bamanan philosophy of speaking is not meant to be limited to the need for a person to speak since he can speak but rather refers to the use of a speech that has all its necessity and its usefulness, not only for the speaker but also the interlocutor and the public to which it is addressed. So, they named speech in their dialect "Kuma", which means "to speak" and at the same time, this term in its reverse "maku" which means "to be silent, so if a person has nothing to say d 'important, useful, that she keep quiet. Therefore, Bamanan society is not an oral society where people talk a lot, but a society where speech is considered sacred and where one should not speak to speak, but rather speak when there is the need and need the usefulness of speaking and also when this speech is useful to the interlocutor, to the public. Moreover, there is another concept, "palaver" or "palaver tree", which edifies not only on the importance of the word but also its sacredness because the speech which is used there is not a futile speech; it must put an end to the disputes, misunderstandings, tensions that settle between members of society. This concept, relatively new in some parts of the world, is an ancestral practice of the black continent, used to discuss and resolve conflicts within a community.

Regarding the different definitions of the word "palaver", in traditional societies, assemblies bring together community members and where information is exchanged, decisions are made in Africa, 
trial before a customary court. ${ }^{*}$ The palaver is a custom of meeting and creation or maintenance of social bonds. It appears as a real social institution in which all or part of the community of a village participates. This custom also makes it possible to settle a dispute without the protagonists being harmed. (Jacques, 1986) Very often, a village has a traditional house or another dedicated place, serving as a place of a palaver ("palaver box", "palaver tree". Depending on the region, the palaver can be held under the palaver tree, usually a baobab $b^{\dagger}$, or in a special building reserved for this purpose. This is the case of Toguna (variable spelling: togouna, to'guna), of the Dogon Country, in Mali, low structure note reserved for men. In his autobiography, Nelson Mandela, born in Transkei to a Xhosa family, quotes the tribal meetings held regularly at the Great Abode. (Mandela, 2013) Among the Baoulés, depending on the circumstance, one can meet under the village chief's apatame (traditional "arbor"), generally located in front of his house. However, the chief can also go himself to the persons concerned. According to Godefroy Bidima in his book "La palabre. Une jurisdiction de la parole" (1997), among the Fangs and Bulu of Central Africa, the palaver takes place in a guardhouse called Aba. Formerly the Aba was considered the House of Men and was the place par excellence for public debate. (Bidima, 1997) In many western African ethnic groups, speech is not only sacred but also in their philosophy, it is as important to speak, to talk about the problems that undermine society, to talk to each other than to use a word that is both useful and necessary. This is why certain sacred places are consecrated not only to the word but this one, by its importance, necessity, and utility, is considered sacred, and it is its sacredness that gives it all its importance, its usefulness, etc.

To consult each other by speaking, however, by using an important, valiant, useful, and necessary speech so that this discussion, this consultation is not in vain, that they can have all their meaning. Under the palaver tree, not only the way of speaking, what kind of speech to use, but also the personalities who must sit there are also designated according to certain rigorous criteria because it is necessary to discuss the serious problems that threaten the peaceful life from the city. These personalities, who are generally old people who have lived so many years, so many experiences, know in-depth and upstream all that is happening in the city use both their wisdom and a certain category of speech to overcome the greatest number of problems that are brought to them. The speeches used there by the personalities are guided by their wisdom of longevity that commands certain respect because they derive their legitimacy from their wisdom acquired through the experiences they have had. The speech that is used thereby these personalities belongs to which category of speech?

\footnotetext{
* Éditions Larousse, « Définitions : palabre - Dictionnaire de français Larousse » sur www.larousse.fr (consulté le 14 Novembre 2020)

$\dagger$ Ibid.
} 


\section{$8 \quad$ Analysis of some expressions}

In fact, according to many West-African cultures, there is a categorization of words that different age groups in society use. Thus are distinguished on the one hand the "tólon kúma", on the other hand, the "kúmaba" and the "fàniya kúma" among the Dioula of the Ivory Coast and "Ngalo kúma" according to the bamanan of Mali and the "tiysn kúma". (Derive, 2016) The first of these two denominations can be translated as "playful speech", "entertainment speech" because the determinant tólon means "game, entertainment, joke" and the substantive kúma designates "speech", "discourse". The second can be translated as a "serious, important word" that has value and whose use is useful and necessary. The "fàniya kúma" or "Ngalo kúma" which designates the "lie" is a proven departure from a criterion of factual truthfulness, of little relevance in this context, that a production of the imaginary which has no impact on the philosophical search for truth. Finally, the "tìyen kúma" means "speeches of truth". The speeches used in "the palaver" or "under the palaver tree" by the personalities designated in the matter can be classified as "tìzn kúma", "speech of truth" because it serves to solve problems, whether they are complexes or less, which undermine the city. The "tìyn kúma" is also used in certain sacred places and circumstances requiring the truth to be spoken. As for the "kúmaba", they are also used in certain sacred places and certain circumstances, among others by the griots when they go to seek the hand of a girl at her parents for any young person, both, of course, come from the families who have an important status in society. The "griot" uses the "kúmaba" because the cause he left is all the more important as his arrangement gives it certain importance and value. "Griots" also use "kúmaba" to resolve disagreements, discord, or conflict between two people or two families. The "tólon kúma" is "playful, entertaining, joking speeches" by young boys, girls when they are having fun, and by some adults when they are joking. We are particularly talking about kinship with jokes. Indeed, "Joke kinship" is a relationship between two people in which one is allowed by custom, and in some cases, compelled to tease or make fun of the other; the other, for his part, should not take offence. (Radcliffe-Brown, 1968) This joking relationship is an important link in social cohesion. It perpetuates social peace. The speaker and the interlocutor who tease each other within this concept of kinship with jokes use "tólon kúma". They do not consider them, that is to say, that the words used in these "tólon kúma", whoever they are, as virulent as they are, as aggressive as they are, are tolerated by them. The use of "fàniya kúma" or "Ngalo kúma", which designates "the lie", is rarefied in the sense that they do not have an important utility, demanding playing a significant role in such or such circumstance. Sometimes their use can be useful; that is to say, the other three genera cannot be used in an exceptional situation, only the "fàniya kúma" or "Ngalo kúma" are used. For example, two people or two families are in conflict, the mediator, knowing that if he speaks the truth "tìyen kúma", will dramatize the conflict situation, cannot make use of either the "kúmaba" or the "tólon kúma", he will use "fàniya kúma" or "Ngalo kúma" which at that time play the role of "tìyen kúma" and "tìysn kúma". In addition, in the

* Ibid. 
"kúmaba", there are the etiological accounts "ngálen kúma" or the historical chronicles "kó kìro".

\section{Conclusion}

In this paper, the analysis is focused on the concept of speech in certain ethnic groups in West Africa. In other words, the author has tried to highlight the conception of these ethnic groups around the notion of even speech. Thus, in the sub-topic dedicated to the classification of speech as "ordinary speech" and "sacred speech", the differentiation between these two concepts was discussed. "ordinary speech" does not mean simple or unnecessary speech. In contrast, it is both very structured and well elaborated. At the same time, the sacred discourse in West Africa refers to the ritual. Ritual and sacred speeches take a formalized form of everyday speech. In these ethnic groups in West Africa, it is through orality, and therefore speech, that knowledge is transmitted. This is also why the speech has been considered as having status, possessing an art and a power that gives it its sacred character.

\section{REFERENCES}

[1] _. La littérature orale, page 2, téléchargeable sur : http://ekladata.com/5AaOUPzjSCmTLwNn1IxGUbpqpsA/litterature-orale.pdf

[2] «L'arbre à palabres, concept africain à succès | Slate Afrique », Slate Afrique, 1er mars 2011 (lire en ligne [archive], consulté le 15 Novembre 2020)

[3] Amoa, U. (2006). Parole africaine et poétique, Schéma de Métacommunication et Pratiques linguistiques en Afrique. Synergies Afrique Centrale et de l'Ouest, (1).

[4] Barbe, R. H. S. (2019). Les traditions orales en Afrique: une exploration du conte comme source d'inspiration du théâtre moderne africain. Horizons/Théâtre. Revue d'études théâtrales, (13), 54- 67.

[5] Bidima, J. G. (1997). La palabre. Une juridiction de la parole.

[6] Dembele, A. (2015). Parler comme un conte, ou l'art de transmettre la connaissance en Afrique. Hermes, La Revue, (2), 243-249.

[7] Derive, J. (2016). La littérature orale traditionnelle, un instrument d'éducation? L'exemple des Dioula de Kong (un groupe manding de Côte-d'Ivoire). Nordic Journal of African Studies, 25(3\&4), 10-10.

[8] Fonkoué, J. (2009). La parole dans la tradition philosophique africaine: le statut de la parole dans la pensée morale égyptienne de la période pharaonique. Menaibuc.

[9] Geneviève, C. G. (1965). Ethnologie et langage. La parole chez les Dogon. Paris, Lambert Lucas.

[10] Guédou, G. A. G. (1985). Xó et gbè, langage et culture chez les Fon (Bénin) (Vol. 4). Peeters Publishers.

[11] Jacques, Chevrier. (1986), L'Arbre à palabres — Essai sur les contes et les récits traditionnels d'Afrique noire, Paris, Hatier, , 384 p. (ISBN 2-7473-0453-1) 
[12] Labatut, R. (1987). La parole à travers quelques proverbes peuls du Fouladou (Sénégal). Journal des africanistes, 57(1), 67-75.

[13] Laditan, A. O. (2004). De l'oralité à la littérature: métamorphoses de la parole chez les Yorubas. Semen. Revue de sémio-linguistique des textes et discours, (18).

[14] Maliki, A. B. (1984). Bonheur et souffrance chez les Peuls nomades.

[15] Mambounggou, J. (1997). Littérature orale et civilisation de l'oralité en Afrique: Quelques barrières à lever pour une approche objective de la culture africaine moderne. 불어문화권연구 (Revue dEtudes Francophones), 7.

[16] Mandela, N. (2013). Un long chemin vers la liberté. Fayard.

[17] Mbathio Sall, L'importance de la tradition orale pour les enfants : cas des pays du Sahel. A retrouver : http://origin-archive.ifla.org/IV/ifla65/65mb-f.htm

[18] Muke, Simon. (2008) « Transmission de la tradition orale africaine en exil », Jacques Besson éd., Hériter, transmettre : le bagage de bébé. Érès, pp. 119-130.

[19] Niane, D. T. (1960). Soundjata: ou, L'épopée mandingue. Présence africaine.

[20] Paulette Roulon-Doko. Le statut de la parole. Ursula Baumgardt et Jean Derive. Littératures orales africaines. Perspectives théoriques et méthodologiques, Karthala, pp.33-45, 2008, Tradition orale. ffhalshs-00720174ff

[21] Radcliffe-Brown, A. R. (1968) «La parenté à plaisanteries », chap. 4, dans Structure et fonction dans la société primitive, trad. de l'anglais par Françoise et Louis Marin, Paris, Éditions de Minuit, p. 158.

[22] René Philombe, Nnan Ndenn Bobo, Yaoundé. (1994). Édition du CRAC, , p. 7.

[23] Roulon-Doko, P. (1998). Chasse, cueillette et cultures chez les Gbaya de Centrafrique (pp. 540-p). l'Harmattan.

[24] Thomas, L. V. (1993). Le verbe négro-africain traditionnel. Religiologiques, Sciences humaines et religion, (7), 1-16.

[25] Vincent, Zanetti. (1990) , « Le griot et le pouvoir », Cahiers d'ethnomusicologie (Website) 